\title{
Young Buyers: Shopping Enjoyment and Obsessive-Compulsive Buying
}

\author{
Ayaz Samo ${ }^{1}$ Hamid Shaikh $^{2} \quad$ Maqsood Bhutto $^{3} \quad$ Fiza Rani $^{3} \quad$ Fayaz Samo $^{2 *}$ Tahseen Bhutto ${ }^{2}$ \\ 1.School of Business Administration, Shah Abdul Latif University, Khairpur, Sindh, Pakistan \\ 2.School of Business Administration, Dongbei University of Finance and Economics, Dalian, China \\ 3.Sukkur Institute of Business Administration, Sindh, Pakistan
}

\begin{abstract}
The purpose of this paper is to evaluate the relationship between hedonic shopping motivations and obsessivecompulsive shopping behavior from youngsters' perspective. The study is based on the survey of 615 young Chinese buyers (mean age=24) and analyzed through Structural Equation Modelling (SEM). The findings show that adventure seeking, gratification seeking, and idea shopping have a positive effect on obsessive-compulsive buying, whereas role shopping and value shopping have a negative effect on obsessive-compulsive buying. However, social shopping is found to be insignificant to obsessive-compulsive buying. The study has a number of implications. Marketers should display more information about latest trends and fashions, as young buyers are found to shop for ideas and information. Managers should design the layouts with more exciting and impressive features, as these buyers are found to shop for adventure and gratification. Salesmen should take greater care into consideration while offering them to buy products such as gifts, souvenir etc. for their dear ones, as these buyers are less likely to enjoy buying for others. Moreover, business managers should less rely on discount promotions, as this consumer segment is found to be less likely to shop for discounts and bargains. This study contributes to the literature by investigating the relationship between hedonic shopping motivations and obsessive-compulsive buying of young Chinese buyers, which is found to be lacking in the literature so far according to the best of authors' knowledge.
\end{abstract}

Keywords: Hedonic shopping, Obsessive-compulsive buying, Young consumers, China. DOI: $10.7176 / \mathrm{EJBM} / 11-3-15$

\section{Introduction}

The world is replete with buyers. Buying is recognized as a socially acceptable activity. It allows consumers to receive hedonic value such as instant sensory stimulation (Babin et al., 1994) or immediate gratification (Elliott, 1994). These factors might have contributed to the enhancement of obsessive-compulsive buying behavior which stems from anxiety, stress, and depression (McElroy et al., 1994). Prior research studies on obsessivecompulsive characteristics of human beings are only carried out from psychology perspective regardless of buying activity, while research studies carried out on compulsive buying in relation to hedonic shopping motivations imply that there may exist a positive relationship between hedonic shopping motivations and obsessive-compulsive buying (Babin et al., 1994). Obsessive-compulsive buyers show persistent, repetitive buying behavior in response to negative occasions and bad feelings (O'Guinn and Faber, 1989). Thereby, compulsive buyers often go shopping obsessively for hedonic purposes in order to escape from adverse feelings and enjoy positive feelings instead (Rindfleisch et al., 1997, Roberts et al., 2006); express their improved selfimage as well as social image (Dittmar, 2007, Escalas and Bettman, 2005, Kukar-Kinney et al., 2012). Moreover, obsessive-compulsive buyers are found to seek sensation and arousal (Bridges and Florsheim, 2008).

Customers have unabated desire for hedonic shopping experiences (Arnold and Reynolds, 2003). Hedonic shopping motivations account for greater value for consumers to carry on shopping activity (Babin et al., 1994). Hedonic values such as fantasy and emotive factors are the main motivators for shopping and consumption (Hirschman and Holbrook, 1982). It is found that some consumers, especially women, explain their shopping activity as an expression of love (Otnes and McGrath, 2001). Batra and Ahtola (1991) describe hedonic shopping motivations of consumers as obtaining pleasure and excitement while shopping. Moods, fantasies, and emotions are found to be the main sources of motivation in modern shopping atmosphere (Anderson et al., 2014, Rayburn and Voss, 2013). These associations imply that hedonic shopping motivations are more likely to be sought by these buyers.

Additionally, it is found that obsessive-compulsive buying has increasingly become a problem in nonWestern countries too (Unger et al., 2014) implying that Western countries do not solely face this problem, nevertheless contextual, sociocultural, and environmental factors may play the role differently in generating hedonic motivations and obsessive-compulsive buying behaviors (Horváth et al., 2013). For example, it is found that culture has a significant impact on how people manage anxiety and stress (Chun et al., 2006). In addition to it, characteristics such as available means of entertainment, stimulation, and escape from routine problems, or country's general wealth of a nation, may impact the motivation and development of this phenomenon.

Despite significant differences are found between developed and emerging economies, and the fact that 80 
percent of the world's population exists in transitional and emerging countries (Steenkamp and Burgess, 2002), much of the research studies have been undertaken on developed countries. It is rather scarce, fragmented literature found about obsessive-compulsive buying in emerging societies. Young Chinese consumers, despite being in an emerging economy, are growing up in a better atmosphere with improving financial conditions. They can afford to spend a large amount of money on entertainment products such as; gaming, sports, movies, traveling, and dining out. The improving life standard of Chinese consumers opens up the healthy and potential business opportunities for national and international companies (Ngai and Cho, 2012). Moreover, examining young Chinese consumers' behavior is valuable because they form a growing market segment both in numbers and financial power (Mangleburg et al., 2004). Youngsters generally show higher courage to take risks (Dayan et al., 2010) as shown by their tendency to quickly embrace innovative products and brands available in the marketplace.

Therefore, it is essential to study the impact of hedonic shopping motivations on the obsessive-compulsive buying behavior of young Chinese buyers in order to better understand what hedonic motivations these consumers attempt to achieve while shopping. This study contributes the valuable consumer insights to the literature by investigating the relationship between hedonic shopping motivations and obsessive-compulsive buying behavior of young Chinese consumers. Moreover, to the best of authors' investigation and knowledge, there is no research study conducted until now that investigates this phenomenon on young consumers. In this way, current study adds to previous knowledge on obsessive-compulsive buying behavior by evaluating on young consumers; the relationship between obsessive-compulsive buying and hedonic shopping motivations such as; gratification seeking, adventure seeking, idea shopping, role shopping, social shopping, and value shopping. Also, we propose relevant valuable consumer insights for the marketing and business managers as these consumers constitute a large (Ridgway et al., 2008) and growing (Neuner et al., 2005) market segment, and evidence suggests they show different motivations and behaviors from other consumers (Horváth et al., 2015).

\section{Literature Review and Hypotheses Development}

\subsection{Obsessive-compulsive Buying Behavior and Hedonic Shopping Motivations}

Compulsive buying is defined as an uncontrollable, persistent, and repetitive shopping behavior that consumers develop in order to gain relief from stress and negative feelings and often bring about harmful consequences (Faber and O'Guinn, 1989, Faber and O'Guinn, 1992). It is reported that approximately 1 percent to 6 percent of the world's population is estimated to suffer from compulsive shopping (Faber and O'Guinn, 1989, Faber and O'Guinn, 1992). It relates to the problems such as anxiety, depression, and bad mood (Black et al., 1998, Lejoyeux et al., 1997, McElroy et al., 1994, Schlosser et al., 1994). (Nataraajan and Goff, 1991) proposed two types of compulsive buying: obsessive-compulsive disordered buying and impulse-control disordered buying. Little research has been carried out on obsessive-compulsive buying behavior compared to impulsive buying. However, there are some basic disturbances shared between obsessive-compulsive and impulsive disordered buying behavior (McElroy et al., 1994). The niceties are found to be blurred between what is desired buying and what is undesired buying for obsessive-compulsive buyer due to the fluctuations caused by time and situation (Kozak and Foa, 1994).

Baumeister (2002) defines the emotions and feeling that are derived from obsessive-compulsive buying constitute the motivation factors for consumers to shop. In the earlier research findings, it is shown that hedonic shopping motivations are related to individual's obsessive-compulsive buying behavior (Rook and Hoch, 1985, Tifferet and Herstein, 2012). These hedonic shopping dimensions are based on consumers subjective evaluations of fun, playfulness, and pleasure received from obsessive-compulsive buying (Babin et al., 1994). Pleasure is believed to be the main motivator for consumers shopping experience (Gültekin and Özer, 2012) and it develops obsessive-compulsive buying as a result (Babin et al., 1994).

\subsection{Dimensions of Hedonic Shopping Motivations}

\section{Adventure Seeking}

Shopping with a desire to adventure, wonder, and stimulation refers to adventure seeking while shopping. It denotes excitement and implies that shoppers want to experience fun and novelty while they are shopping (To et al., 2007a). It is found that obsessive-compulsive buyers in emerging countries tend to show a greater inclination towards adventure shopping (Horváth and Adıgüzel, 2017). It creates a sense of awe and joy and makes them feel as if they are visiting a unique world. (Zuckerman, 1993) relates obsessive-compulsive urges to legal, financial, social, and physical dangers, as shopping stimulates them to the non-rational behavior exhibited in gambling and gaming (McDaniel and Zuckerman, 2003), thrilling sports, (Jack and Ronan, 1998), and lottery purchasing (George, 2002). Adventure seeking while shopping indicates that obsessive-compulsive shoppers quite often search for exciting experiences. Hence, we hypothesize that:

H1. Adventure seeking is positively related to obsessive-compulsive buying. 


\section{2. $\quad$ Gratification Seeking}

Arnold and Reynolds (2003) describe that shoppers look for relief from stress and negative mood and treat themselves special while their shopping activity. Rook and Gardner (1993) showed a link between mood and obsessive-compulsive buying. They described that shopping impulses for these consumers have a weak relationship with deliberate decisions and spontaneous actions. Such consumers are more likely to face adverse consequences resulting from their unplanned shopping decisions in search of instant gratification (Hoch and Loewenstein, 1991). However, it is found that these buyers do not worry about the costs and adverse outcomes during their shopping. The immediate sense of relief that they receive from gratification while shopping is their major implicit objective. They usually get attracted by pleasurable experiences, no matter how short-lived they may be (Jones et al., 2003, Rook, 1987). Hence, we hypothesize that:

$\mathrm{H} 2$. Gratification seeking is positively related to obsessive-compulsive buying.

\section{Idea Shopping}

Idea shopping refers to gathering information about latest products and trends while shopping. It includes the information needs that consumers attempt to fulfill by observing different products, ideas, and experiences. Majority of the buyers report that their intention to go shopping is not mere buying the products but to collect information about new products and services in the marketplace. They show that they are inclined to keep up with innovative products and latest fashions (Arnold and Reynolds, 2003). There are two types of motivations: utilitarian motivations and hedonic motivations. Some consumers go shopping for utilitarian objectives such as convenience, cost saving, selection, and availability, while others do so for hedonic shopping motivations such as status, gratification, excitement, and authority. Negative consequences do not bother these buyers on the spur of the shopping moment (Rook, 1987). They are easily attracted by internal and external incentives in the form of information about the products they like (Rook and Fisher, 1995). However, external stimuli tend to increase obsessive-compulsive buying (Iyer, 1989). These stimuli create the urge for the consumers to buy products obsessively. Hence, we hypothesize that:

H3. Idea shopping is positively related to obsessive-compulsive buying.

\section{Role Shopping}

Role shopping refers to obtaining pleasure while consumers shop for others. They believe shopping for dear ones will give them a sense of bonding with them. It is also found in the earlier research studies that consumers feel happy when they look around to buy a gift for their family and friends (Arnold and Reynolds, 2003). However, in some research studies it is found that in some cultures consumers are less likely to enjoy buying for others (Falode et al., 2016), while Rook and Fisher (1995) indicate that obsessive-compulsive buyers tend to avail discounts, bonuses or prizes from the promotional campaigns and get themselves gratified by buying a gift for their dear ones (To et al., 2007b). Hence, we hypothesize that:

H4. Role shopping is positively related to obsessive-compulsive buying.

\section{Social Shopping}

Social shopping refers to enjoyment a shopper receives while shopping with his/her family or friends and intends to bond with others (Arnold and Reynolds, 2003). Obsessive-compulsive buyers usually prefer shopping alone. It is found that 74 percent of them choose to shop alone (Black et al., 1998, Schlosser et al., 1994) for they believe shopping will relieve their stress (Desarbo and Edwards, 1996), they believe it's their private pleasure (Woodruffe, 1997) and often lose and mismanage their time (Kellett and Bolton, 2009). They often feel guilt, regret, and shame because of frequent shopping proclivity (O'Guinn and Faber, 1989). Therefore, they want to shop alone so that others may not see how often, how much, and what they buy. That is why they turn to shop online, keep themselves unobserved, and avoid interacting with others while shopping (Kukar-Kinney et al., 2009). As a result, they often find the ways to hide their shopping behavior (Ridgway et al., 2008), due to these reasons, obsessive-compulsive buyers may be less likely to enjoy social shopping as compared to other buyers. Hence, we hypothesize that:

H5. Social shopping is negatively related to obsessive-compulsive buying.

\section{Value Shopping}

Value shopping refers to hunting for discounts, bargains, or sales while shopping. Consumers' ideal choice is to look for the quality products and buy them on discount. They extend their attempt to negotiate for a reduced price for a quality product. They believe winning a discount is a valuable achievement. They consider shopping activity as a challenge to win a discount (Arnold and Reynolds, 2003). Also, Kukar-Kinney et al. (2012) indicate that obsessive-compulsive buyers compensate their negative with the discounts and hence become more price conscious in their shopping behavior. Additionally, (Kukar-Kinney et al., 2016) investigated the tendency of compulsive buyers by showing a positive correlation between obsessive-compulsive buying and coupon size. For that, marketers use certain promotional cues to attract these consumers (Youn and Faber, 2000). Such promotional incentives and limited offer periods direct buyers behavior to buy products compulsively (Xu and Huang, 2014, Zheng et al., 2013). Furthermore, bonuses, volume deals, price discounts, and packs are found to stimulate obsessive-compulsive buying (Pettigrew et al., 2015, Xu and Huang, 2014). Hence, we hypothesize 
that:

H6. Value shopping is positively related to obsessive-compulsive buying.

\section{Research Methodology.}

\subsection{Survey Method and Data Collection}

We used convenience sampling technique to collect the data from young Chinese shoppers in March 2018. The sample consists of 76 percent of female respondents with 24 years average age (see Table 1). We choose more female respondents because obsessive-compulsive buying is more common in females than in males (Hou and Elliott, 2016). Since young buyers in China form a market which is growing bigger in number and richer in wealth, it is hence useful to investigate their hedonic shopping behavior (Mangleburg et al., 2004). Furthermore, they tend to be risk takers and adopt new products more rapidly (Dayan et al., 2010).

The data were mostly collected from university students. Since the questionnaire was well defined, we collected 30 percent of the questionnaires on physical question papers in person and 70 percent of the questionnaires were collected through a social media channel 'WeChat' which is very popular mobile application in China (Gan, 2017).

To test the hypotheses shown in Fig. 1, we used structural equation modeling (SEM) pursuing the study of ( $\mathrm{Li}$ et al., 2018) which was used in a comparative study on online and offline shopping behavior (Cao et al., 2012). We used Smart PLS 3.0 software to analyze the data. This is because PLS-SEM is effective software in our study for prediction-oriented goal as our study investigates the predictive relationship between hedonic shopping motivations and obsessive-compulsive buying rather than confirmatory. Moreover, it deals with various problems efficiently with fewer identification issues when the range of sample size is wide (Hair et al., 2011). For the outer model evaluation, reliability and validity measures are assessed through a PLS-SEM algorithm. For inner model evaluation, bootstrapping is performed with 5000 subsamples to test the hypotheses.

\subsection{Measures}

We distributed a total number of questionnaires around 1600: sending about 1400 online and 200 offline. We received $19 \%$ and $72 \%$ response rate respectively. The obsessive-compulsive buying construct is taken from (Ridgway et al., 2008), and analyzed through a two-item questionnaire (Lo and Harvey, 2011). Hedonic shopping motivations are measured through adventure seeking (ADV), gratification seeking (GRA), idea shopping (IDE), role shopping (ROL), social shopping (SOC), and value shopping (VAL) from the study of (Arnold and Reynolds, 2003). We used a five-point Likert scale to measure the variables: 5 representing strongly agree and 1 representing strongly disagree. We also included sociodemographic questions such as age, gender, education, and income for a thorough understanding of our sample. We first developed the questionnaire in English and then got it translated and back-translated into Chinese by two professional Chinese translators for content validity.

\subsection{Missing Values, Composite Reliability, and Validity}

Results show that the values of composite reliability are greater than 0.70 which is the acceptable minimum criterion for reliability. In PLS-SEM, composite reliability is known as Dillon-Goldstein's rho which is well met for all the constructs except adventure seeking shown in Table 2. The values of convergent validity for all the constructs are greater than minimum required values of 0.50 (see Table 2), as average variance extracted explains more than $50 \%$ of variance extracted (Li et al., 2018). Hence it validates the convergent validity. For discriminant validity, we compared square of inter construct correlation coefficients with the square root of average variance extracted. The square root of average variance extracted exceeds the values of inter construct correlation and hence support discriminant validity (see Table 3) (Fornell and Larcker, 1981). There is no missing value found in the study, indicating that the results are free from any potential alterations. The study also meets the VIF (variance inflation factor) required values (Diamantopoulos and Winklhofer, 2001) to ensure that there is no multi-collinearity among independent variables in the research model (see Table 4). Hence, the study meets all the basic required criteria to process the date further for the results (Hair Jr et al., 2016).

We next assess the structural model and find the reliability values $\mathrm{R}$ square 0.43 and adjusted $\mathrm{R}$ square 0.43 (see Table 5) which explain the degree that independent variables (hedonic shopping motivations) explain the dependent variable (obsessive-compulsive buying) at 0.05 significance value. The variable items are found to be greater than the minimum required value of 0.708 (see Table 6) and hence are significant (Hair Jr et al., 2016, Li et al., 2018).

\section{Results and Discussion}

The living conditions of Chinese people are improving due to China's ever-improving economy. The results demonstrate a significant relationship between obsessive-compulsive buying and hedonic shopping motivations such as gratification seeking, adventure seeking, idea shopping, role shopping, and value shopping do exist for 
these consumers except for social shopping (see Table 7). Three hedonic motivations namely: gratification seeking, adventure seeking, and idea shopping are found to be positively significant to obsessive-compulsive buying. This may be due to the fact that Chinese are found to be high rollers in the earlier studies (Zeng and Forrest, 2009). According to these consumers, shopping is considered to be a pleasurable activity with a touch of adventure, gratification, and discovery. On the other hand, role shopping and value shopping are found to be negatively significant to obsessive-compulsive buying. Interestingly, social shopping is found to be insignificant to obsessive-compulsive buying.

Adventure seeking is found to be a positive significant relationship to obsessive-compulsive buying confirming the earlier studies on emerging markets (Horváth and Adıgüzel, 2017) Hypothesis H1is supported. There is also found to be a strong correlation between adventure seeking and obsessive-compulsive (Khare, 2012). Consumers like to visit frequently the retail shops where they expect to receive adventures such as discovery, innovative layout, and entertaining environment (Babin et al., 1994, Jones, 1999). Such adventure may not be the primary purpose of these consumers but an emotional state that they want to indirectly satisfy with hedonic experiences.

Gratification seeking is found to be a major motivation for these consumers that positively contributes to obsessive-compulsive buying (Novak et al., 2000). Hypothesis H2 is supported. The earlier established findings on the research study where the impact of music was found to be a contributing factor for more obsessivecompulsive buying than just displaying motionless images (Adelaar et al., 2003). Obsessive-compulsive consumers tend to enjoy a great deal of gratification while shopping in order to relieve themselves of stress and anxiety and hence it generates more obsessive buying.

Idea shopping is found to be positively contributing to obsessive-compulsive buying. Buyers tend to learn more new ideas about new fashions, styles, and trends attracting buyers to make more frequent visits even at distance (Davis and Hodges, 2012). Hypothesis H3 is supported. This is because external cues and information guidelines direct consumers to know about themselves. They enjoy window shopping and learn new ideas as well. Keeping in contact with the latest trends and fashions are one of the hedonic motivations of young Chinese consumers.

Role shopping is found to be negatively contributing to impulsive buying. Hypothesis $\mathrm{H} 4$ is rejected. Authors believe this may be due to the fact that gift giving or shopping for others has been meant differently in different cultures (Belk, 1984). For example, in emerging countries, buying gifts for others was considered more to be a utilitarian factor than a hedonic motivation (Green and Alden, 2010). This holds true for young Chinese consumers too as China is an emerging economy.

Social shopping is found to have an insignificant relationship to obsessive-compulsive buying. Young Chinese buyers are less likely to enjoy shopping for social purposes. Hypothesis H5 is rejected. It is found to be contrary to the findings of Falode et al. (2016) who reported that social events encourage obsessive-compulsive buyers to make more purchases obsessively (Mattila and Wirtz, 2008), however, there are useful insights for the marketers nevertheless such as; on social occasions, marketers should keep limited budget to spend on persuading young Chinese consumers to buy their products. Young Chinese consumers believe that social events are not suitable for shopping and similarly, while shopping, they are less likely to socialize and make friends with others. For them, shopping is not a social event.

Value shopping is found to have a negative significant relationship to obsessive-compulsive buying. It implies that young Chinese consumers are less likely to be price sensitive. However, consumers are generally more likely to be value conscious in emerging markets owing to lower purchasing power, less willingness to buy products on credit and demand being more price elastic (Brouthers and $\mathrm{Xu}, 2002$ ). Moreover, these consumers may fear uncertainties in terms of quality of the products (Erguncu and Yildirim, 2015). Therefore, they tend to give higher importance to product value than its price (Cayla and Arnould, 2008, Pandey and Devasagayam, 2015), and use price as a signal to perceive quality (D'Andrea et al., 2010). In addition, most of the young Chinese consumers are students and have less purchasing power which implies that they may need to think more wisely before they make a purchase decision and maximize the returns (Pandey and Devasagayam, 2015). Thus, it requires more efforts and reduces the hedonic value for these consumers to shop for products for sale.

\section{Implications}

The study offers a number of fundamental customer insights for business firms for effectively building this customer base. Marketing managers should creatively design retail layout which may give these buyers a feeling of wonder, adventure, and discovery. Retailers should keep product assortments innovatively so that these consumers amuse themselves with a variety of product ideas and information. Marketing managers should ensure the quality of products instead of price reductions for these consumers tend to value quality more than price reductions. The salespersons should be more careful while persuading young Chinese buyers to buy gifts for their dear ones because these buyers are less likely to shop for others.

Simultaneously, marketers should carefully comprehend the true nature of these buyers regarding buying 
gifts and keepsakes for they are more susceptible to changing preferences and switching brands. Business organizations may not develop a customer base (Horváth and Birgelen, 2015). Additionally, they accrue excessive and uncontrollable debts (O'Guinn and Faber, 1989) and consequently, they refrain from shopping completely.

Obsessive-compulsive buyers are prone to engage at first sight. Business managers should ensure the exciting shopping experience of these consumers in terms of adventure: by designing an innovative shopping process gratification: by customizing an exciting shopping environment, and idea: by showcasing a variety of products. On the other hand, for role shopping being negative significant to obsessive-compulsive buying, salespersons should be mindful while recommending this consumer segment to buy products as gifts for others.

Obsessive-compulsive buyers are more likely to be unstable customer base in the long run. Therefore, ethically marketers should take greater care of the sensitive touchpoints of this vulnerable consumer segment while advertising products to them. Previous studies suggest that obsessive-compulsive buyers often face adverse consequences after their shopping (Faber and O'Guinn, 1992). It may lead them to financial distress and mental stress (Horváth et al., 2015).

\section{Limitations and Future Study}

This research study has some limitation. First, it is based on cross-sectional data. It may miss out on the customer insights that would possibly be received by collecting time series data. It would add to understanding the varying behavior of these obsessive-compulsive buyers with respect to the dimensions of hedonic shopping motivations.

Second, most of our sample comprises students and have low purchasing power. This may affect the hedonic shopping motivations as pleasure is a subjective term and tends to be a different experience for different income groups.

A comparative study on the gender difference in the current phenomenon could also be investigated for men are found to be more susceptible to seek convenience and information, while women show greater interest in product assortment and web browsing for uniqueness (Noble et al., 2006).

\section{References}

ADELAAR, T., CHANG, S., LANCENDORFER, K. M., LEE, B. \& MORIMOTO, M. 2003. Effects of media formats on emotions and impulse buying intent. Journal of Information Technology, 18, 247-266.

ANDERSON, K. C., KNIGHT, D. K., POOKULANGARA, S. \& JOSIAM, B. 2014. Influence of hedonic and utilitarian motivations on retailer loyalty and purchase intention: a facebook perspective. Journal of Retailing and Consumer Services, 21, 773-779.

ARNOLD, M. J. \& REYNOLDS, K. E. 2003. Hedonic shopping motivations. Journal of Retailing, 79, 77-95.

BABIN, B. J., DARDEN, W. R. \& GRIFFIN, M. 1994. Work and/or fun: measuring hedonic and utilitarian shopping value. Journal of consumer research, 20, 644-656.

BATRA, R. \& AHTOLA, O. T. 1991. Measuring the hedonic and utilitarian sources of consumer attitudes. Marketing letters, 2, 159-170.

BAUMEISTER, R. F. 2002. Yielding to temptation:Self-control failure,impulsive purchasing,and consumer behavior. Journal of Consumer Research, 28, 670-676.

BELK, R. W. 1984. Cultural and historical differences in concepts of self and their effects on attitudes toward having and giving. ACR North American Advances.

BLACK, D. W., REPERTINGER, S., GAFFNEY, G. R. \& GABEL, J. 1998. Family history and psychiatric comorbidity in persons with compulsive buying: preliminary findings. American Journal of Psychiatry, 155, 960-963.

BRIDGES, E. \& FLORSHEIM, R. 2008. Hedonic and utilitarian shopping goals: The online experience. Journal of Business research, 61, 309-314.

BROUTHERS, L. E. \& XU, K. 2002. Product stereotypes, strategy and performance satisfaction: The case of Chinese exporters. Journal of International Business Studies, 33, 657-677.

CAO, X. J., XU, Z. \& DOUMA, F. 2012. The interactions between e-shopping and traditional in-store shopping: an application of structural equations model. Transportation, 39, 957-974.

CAYLA, J. \& ARNOULD, E. J. 2008. A cultural approach to branding in the global marketplace. Journal of International Marketing, 16, 86-112.

CHUN, C.-A., MOOS, R. H. \& CRONKITE, R. C. 2006. Culture: A fundamental context for the stress and coping paradigm. Handbook of multicultural perspectives on stress and coping. Springer.

D'ANDREA, G., MARCOTTE, D. \& MORRISON, G. D. 2010. Let emerging market customers be your teachers. Harvard Business Review, 88, 115-+.

DAVIS, L. \& HODGES, N. 2012. Consumer shopping value: An investigation of shopping trip value, in-store shopping value and retail format. Journal of Retailing \& Consumer Services, 19, 229-239. 
DAYAN, J., BERNARD, A., OLLIAC, B., MAILHES, A. S. \& KERMARREC, S. 2010. Adolescent brain development, risk-taking and vulnerability to addiction. Journal of Physiology - Paris, 104, 279-286.

DESARBO, W. S. \& EDWARDS, E. A. 1996. Typologies of compulsive buying behavior: A constrained clusterwise regression approach. Journal of consumer psychology, 5, 231-262.

DIAMANTOPOULOS, A. \& WINKLHOFER, H. M. 2001. Index Construction with Formative Indicators: An Alternative to Scale Development. Journal of Marketing Research, 38, 269-277.

DITTMAR, H. 2007. The costs of consumer culture and the "cage within": the impact of the material "good life" and "body perfect" ideals on individuals" identity and well-being. Psychological Inquiry, 18, 23-31.

ELLIOTT, R. 1994. Addictive consumption: Function and fragmentation in postmodernity. Journal of consumer policy, 17, 159-179.

ERGUNCU, S. \& YILDIRIM, G. 2015. How consumer mindset response and long-term marketing effectiveness differ in emerging vs. mature markets. Marketing and Consumer Behavior: Concepts, Methodologies, Tools, and Applications. IGI Global.

ESCALAS, J. E. \& BETTMAN, J. R. 2005. Self-construal, reference groups, and brand meaning. Journal of consumer research, 32, 378-389.

FABER, R. J. \& O'GUINN, T. C. 1989. Classifying Compulsive Consumers: Advances in the Development of a Diagnostic Tool. Advances in Consumer Research, 16, 738-744.

FABER, R. J. \& O'GUINN, T. C. 1992. Clinical Screener for Compulsive Buying | Journal of Consumer Research | Oxford Academic. Journal of Consumer Research, 19, 459-469.

FALODE, B. O., AMUBODE, A. A., ADEGUNWA, M. O. \& OGUNDUYILE, S. R. 2016. Online and Offline Shopping Motivation of Apparel Consumers in Ibadan Metropolis, Nigeria. International Journal of Marketing Studies, 8, 150.

FORNELL, C. \& LARCKER, D. F. 1981. Evaluating structural equation models with unobservable variables and measurement error. Journal of marketing research, 39-50.

GAN, C. 2017. Understanding WeChat users' liking behavior: An empirical study in China. Computers in Human Behavior, 68, 30-39.

GEORGE, B. 2002. The relationship between lottery ticket and scratch - card buying behaviour, personality and other compulsive behaviours. Journal of Consumer Behaviour: An International Research Review, 2, 7-22.

GREEN, R. T. \& ALDEN, D. L. 2010. Functional equivalence in cross-cultural consumer behavior: Gift giving in Japan and the United States. Psychology \& Marketing, 5, 155-168.

GÜLTEKIN, B. \& ÖZER, L. 2012. The Influence of Hedonic Motives and Browsing On Impulse Buying. Journal of Economics \& Behavioral Studies.

HAIR, J. F., RINGLE, C. M. \& SARSTEDT, M. 2011. Journal of Marketing Theory and Practice: From the special issue guest editors. Journal of Marketing Theory \& Practice, 19, 135-137.

HAIR JR, J. F., HULT, G. T. M., RINGLE, C. \& SARSTEDT, M. 2016. A primer on partial least squares structural equation modeling (PLS-SEM), Sage Publications.

HIRSCHMAN, E. C. \& HOLBROOK, M. B. 1982. Hedonic Consumption: Emerging Concepts, Methods and Propositions. Journal of Marketing, 46, 92-101.

HOCH, S. J. \& LOEWENSTEIN, G. F. 1991. Time-Inconsistent Preferences and Consumer Self-Control. Journal of Consumer Research, 17, 492-507.

HORVÁTH, C. \& ADıGÜZEL, F. 2017. Shopping enjoyment to the extreme: Hedonic shopping motivations and compulsive buying in developed and emerging markets. Journal of Business Research.

HORVÁTH, C., ADIGÜZEL, F. \& HERK, H. V. 2013. Cultural aspects of compulsive buying in emerging and developed economies: a cross cultural study in compulsive buying.

HORVÁTH, C. \& BIRGELEN, M. V. 2015. The role of brands in the behavior and purchase decisions of compulsive versus noncompulsive buyers. European Journal of Marketing, 49, 2-21.

HORVÁTH, C., BÜTTNER, O. B., BELEI, N. \& ADiGÜZEL, F. 2015. Balancing the balance: Self-control mechanisms and compulsive buying. Journal of Economic Psychology, 49, 120-132.

HOU, J. \& ELLIOTT, K. 2016. Gender differences in online auctions. Electronic Commerce Research and Applications, 17, 123-133.

IYER, E. S. 1989. Unplanned Purchasing: Knowledge of shopping environment and. Journal of retailing, 65, 40.

JACK, S. \& RONAN, K. R. 1998. Sensation seeking among high-and low-risk sports participants. Personality and Individual differences, 25, 1063-1083.

JONES, M. A. 1999. Entertaining shopping experiences: an exploratory investigation. Journal of retailing and consumer services, 6, 129-139.

JONES, M. A., REYNOLDS, K. E., WEUN, S. \& BEATTY, S. E. 2003. The product-specific nature of impulse buying tendency. Journal of business research, 56, 505-511.

KELLETT, S. \& BOLTON, J. V. 2009. Compulsive buying: a cognitive-behavioural model. Clinical psychology \& psychotherapy, 16, 83-99. 
KHARE, A. 2012. Impact of consumer decision-making styles on Indian consumers' mall shopping behaviour. International Journal of Indian Culture and Business Management, 5, 259-279.

KOZAK, M. J. \& FOA, E. B. 1994. Obsessions, overvalued ideas, and delusions in obsessive-compulsive disorder. Behaviour Research and Therapy, 32, 343-353.

KUKAR-KINNEY, M., RIDGWAY, N. M. \& MONROE, K. B. 2009. The Relationship Between Consumers' Tendencies to Buy Compulsively and Their Motivations to Shop and Buy on the Internet. Journal of Retailing, 85, 298-307.

KUKAR-KINNEY, M., RIDGWAY, N. M. \& MONROE, K. B. 2012. The Role of Price in the Behavior and Purchase Decisions of Compulsive Buyers. Journal of Retailing, 88, 63-71.

KUKAR-KINNEY, M., SCHEINBAUM, A. C. \& SCHAEFERS, T. 2016. Compulsive buying in online daily deal settings: An investigation of motivations and contextual elements. Journal of Business Research, 69, 691-699.

LEJOYEUX, M., TASSAIN, V., SOLOMON, J. \& ADES, J. 1997. Study of compulsive buying in depressed patients. The Journal of clinical psychiatry.

LI, W., BHUTTO, T. A., NASIRI, A. R., SHAIKH, H. A. \& SAMO, F. A. 2018. Organizational innovation: the role of leadership and organizational culture. International Journal of Public Leadership, 14, 33-47.

LO, H.-Y. \& HARVEY, N. 2011. Shopping without pain: Compulsive buying and the effects of credit card availability in Europe and the Far East. Journal of Economic Psychology, 32, 79-92.

MANGLEBURG, T. F., DONEY, P. M. \& BRISTOL, T. 2004. Shopping with friends and teens' susceptibility to peer influence. Journal of retailing, 80, 101-116.

MATTILA, A. S. \& WIRTZ, J. 2008. The role of store environmental stimulation and social factors on impulse purchasing. Journal of Services Marketing, 22, 562-567.

MCDANIEL, S. R. \& ZUCKERMAN, M. 2003. The relationship of impulsive sensation seeking and gender to interest and participation in gambling activities. Personality and Individual differences, 35, 1385-1400.

MCELROY, S. L., KECK, P. E., POPE, H. G., SMITH, J. M. \& STRAKOWSKI, S. M. 1994. Compulsive buying: a report of 20 cases. The Journal of clinical psychiatry.

NATARAAJAN, R. \& GOFF, B. G. 1991. Compulsive buying: toward a reconceptualization. Journal of Social Behavior and Personality, 6, 307.

NEUNER, M., RAAB, G. \& REISCH, L. A. 2005. Compulsive buying in maturing consumer societies: An empirical re-inquiry. Journal of economic psychology, 26, 509-522.

NGAI, J. \& CHO, E. 2012. The young luxury consumers in China. Young Consumers, 13, 255-266.

NOBLE, S. M., GRIFFITH, D. A. \& ADJEI, M. T. 2006. Drivers of local merchant loyalty: Understanding the influence of gender and shopping motives. Journal of Retailing, 82, 177-188.

NOVAK, T. P., HOFFMAN, D. L. \& YUNG, Y.-F. 2000. Measuring the customer experience in online environments: A structural modeling approach. Marketing science, 19, 22-42.

O'GUINN, T. C. \& FABER, R. J. 1989. Compulsive buying: A phenomenological exploration. Journal of consumer research, 16, 147-157.

OTNES, C. \& MCGRATH, M. A. 2001. Perceptions and realities of male shopping behavior. Journal of retailing, 77, 111-137.

PANDEY, S. \& DEVASAGAYAM, R. 2015. The effect of deals and moods on compulsive buying in young adults: A comparison of an indulgence culture and a restraint culture. Journal of Customer Behaviour, 14, 257-270.

PETTIGREW, S., BIAGIONI, N., JONES, S. C., DAUBE, M., KIRBY, G., STAFFORD, J. \& CHIKRITZHS, T. 2015. Sales promotion strategies and youth drinking in Australia. Social Science \& Medicine, 141, 115-122.

RAYBURN, S. W. \& VOSS, K. E. 2013. A model of consumer's retail atmosphere perceptions. Journal of Retailing and Consumer Services, 20, 400-407.

RIDGWAY, N. M., KUKAR-KINNEY, M. \& MONROE, K. B. 2008. An expanded conceptualization and a new measure of compulsive buying. Journal of Consumer Research, 35, 622-639.

RINDFLEISCH, A., BURROUGHS, J. E. \& DENTON, F. 1997. Family structure, materialism, and compulsive consumption. Journal of consumer research, 23, 312-325.

ROBERTS, J. A., MANOLIS, C. \& TANNER, J. F. J. 2006. Adolescent autonomy and the impact of family structure on materialism and compulsive buying. Journal of Marketing Theory and Practice, 14, 301-314.

ROOK, D. W. 1987. The buying impulse. Journal of consumer research, 14, 189-199.

ROOK, D. W. \& FISHER, R. J. 1995. Normative Influences on Impulsive Buying Behavior | Journal of Consumer Research | Oxford Academic. Journal of Consumer Research, 22, 305-313.

ROOK, D. W. \& GARDNER, M. P. 1993. In the mood: Impulse buying's affective antecedents. Research in Consumer Behavior, 6, 1-28.

ROOK, D. W. \& HOCH, S. J. 1985. Consuming impulses. Advances in Consumer Research, 12, 23-27.

SCHLOSSER, S., BLACK, D. W., REPERTINGER, S. \& FREET, D. 1994. Compulsive buying: Demography, 
phenomenology, and comorbidity in 46 subjects. General hospital psychiatry, 16, 205-212.

STEENKAMP, J.-B. E. \& BURGESS, S. M. 2002. Optimum stimulation level and exploratory consumer behavior in an emerging consumer market. International Journal of Research in Marketing, 19, 131-150.

TIFFERET, S. \& HERSTEIN, R. 2012. Gender differences in brand commitment, impulse buying, and hedonic consumption. Journal of Product \& Brand Management, 21, 176-182.

TO, P.-L., LIAO, C. \& LIN, T.-H. 2007a. Shopping motivations on Internet: A study based on utilitarian and hedonic value. Technovation, 27, 774-787.

TO, P. L., LIAO, C. \& LIN, T. H. 2007b. Shopping motivations on Internet: A study based on utilitarian and hedonic value. Technovation, 27, 774-787.

UNGER, A., PAPASTAMATElOU, J., OKAN, E. Y. \& AYTAS, S. 2014. How the economic situation moderates the influence of available money on compulsive buying of students - a comparative study between Turkey and Greece. Journal of behavioral addictions, 3, 173-181.

WOODRUFFE, H. R. 1997. Compensatory consumption: why women go shopping when they're fed up and other stories. Marketing Intelligence \& Planning, 15, 325-334.

XU, Y. \& HUANG, J.-S. 2014. Effects of price discounts and bonus packs on online impulse buying. Social Behavior and Personality: an international journal, 42, 1293-1302.

YOUN, S. \& FABER, R. J. 2000. Impulse buying: its relation to personality traits and cues. ACR North American Advances.

ZENG, Z. L. \& FORREST, D. 2009. High rollers from Mainland China: a profile based on 99 cases. Unlv Gaming Research \& Review Journal, 29-43.

ZHENG, X., LIU, N. \& ZHAO, L. A Study of the Effectiveness of Online Scarce Promotion--Based on the Comparison of Planned Buying and Unplanned Buyingi. the twelfth wuhan international conference on ebusiness, 2013.

ZUCKERMAN, M. 1993. Sensation seeking and impulsivity: A marriage of traits made in biology. The impulsive client: Theory, research, and treatment, 71-91.

\section{Research Model/Conceptual Framework \\ Figure 1 obsessive-compulsive Buyers}

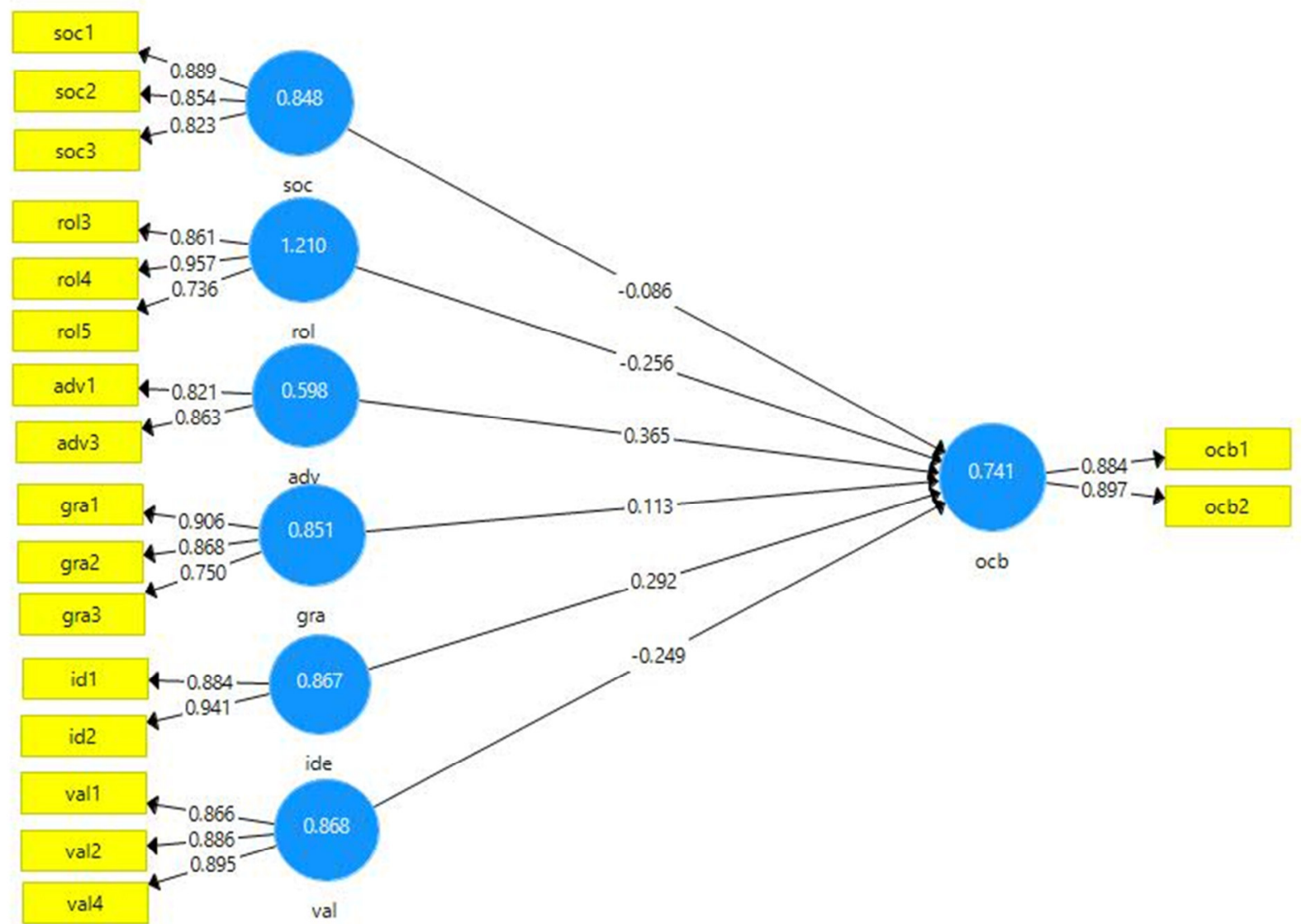

$\mathrm{SOC}=$ social shopping, $\mathrm{ROL}=$ role shopping, $\mathrm{ADV}=$ adventure seeking, $\mathrm{GRA}=$ gratification seeking, IDE=idea shopping, $\mathrm{VAL}=$ value shopping, $\mathrm{OCB}=$ obsessive-compulsive buying 
Table 1. Demographic Profile of Respondents

\begin{tabular}{cccc}
\hline Demographic variable & Category & Frequency & Percent \\
\hline Gender & Male & 147 & 24 \\
& Female & 468 & 76 \\
Age & Below 18 & 11 & 2 \\
& $18-22$ & 402 & 65 \\
Education & $23-27$ & 135 & 22 \\
& Above 27 & 67 & 11 \\
Income/month (RMB) & Bachelors & 456 & 74 \\
& Masters & 108 & 18 \\
& PhD & 20 & 3 \\
& Other & 31 & 5 \\
& Below 3000 & 466 & 76 \\
& $3000-6000$ & 96 & 32 \\
\end{tabular}

Table 2. Indicators' Reliability, Rho, Composite Reliability, and AVE Values Cronbach's Alpha $\quad$ Rho_A Composite Reliability Average Variance

\begin{tabular}{ccccc} 
& & & Extracted (AVE) \\
\hline ADVENTURE & 0.592 & 0.60 & 0.830 & 0.709 \\
GRATIFICATION & 0.799 & 0.851 & 0.880 & 0.712 \\
OCB & 0.740 & 0.741 & 0.884 & 0.793 \\
IDEA & 0.806 & 0.870 & 0.909 & 0.834 \\
ROLE & 0.847 & 1.210 & 0.891 & 0.733 \\
SOCIAL & 0.819 & 0.850 & 0.891 & 0.731 \\
VALUE & 0.859 & 0.870 & 0.914 & 0.778 \\
\hline
\end{tabular}

Table 3. Discriminant Validity

\begin{tabular}{|c|c|c|c|c|c|c|c|}
\hline & adventure & gratification & idea & ocb & role & social & value \\
\hline adventure & 0.84 & & & & & & \\
\hline gratification & 0.72 & 0.84 & & & & & \\
\hline idea & 0.52 & 0.49 & 0.91 & & & & \\
\hline ocb & 0.39 & 0.29 & 0.41 & 0.89 & & & \\
\hline role & 0.34 & 0.39 & 0.20 & -0.23 & 0.85 & & \\
\hline social & 0.40 & 0.44 & 0.24 & -0.14 & 0.67 & 0.85 & \\
\hline value & 0.31 & 0.34 & 0.21 & -0.24 & 0.60 & 0.62 & 0.88 \\
\hline
\end{tabular}

Table 4. Path Coefficient, Significance, and VIF Values

\begin{tabular}{cccc}
\hline Constructs & P.C Value & Sig: Val & VIF Val \\
\hline ADV & 0.365 & 0.000 & 2.33 \\
GRA & 0.112 & 0.014 & 2.34 \\
IDE & 0.292 & 0.000 & 1.44 \\
ROL & -0.256 & 0.000 & 2.08 \\
SOC & -0.085 & 0.106 & 2.24 \\
VAL & -0.248 & 0.000 & 1.82 \\
\hline
\end{tabular}

Table 5. R Square and R Square Adjusted Values

\begin{tabular}{ccc}
\hline & R Square & R Square Adjusted \\
\hline Obsessive-compulsive buyers & 0.43 & 0.43 \\
\hline
\end{tabular}


Table 6. Factor Analysis of Consumer Characteristics

\begin{tabular}{|c|c|c|c|c|}
\hline Constructs & $\begin{array}{l}\text { Composite } \\
\text { Reliability }\end{array}$ & Items & Estimate & $\begin{array}{l}\mathrm{t}- \\
\text { value }\end{array}$ \\
\hline \multirow[t]{2}{*}{ Adventure seeking } & $0.830(\mathrm{a}=0.592)$ & I find shopping stimulating & 0.82 & 27.66 \\
\hline & & To me, shopping is an adventure & 0.86 & 34.52 \\
\hline \multirow[t]{3}{*}{ Gratification seeking } & $0.880(a=0.799)$ & $\begin{array}{l}\text { When I am in bad mood, I go shopping to } \\
\text { make me feel better }\end{array}$ & 0.90 & 63.69 \\
\hline & & To me, shopping is a way to relieve stress & 0.86 & 41.98 \\
\hline & & $\begin{array}{l}\text { I go shopping when I want to treat myself to } \\
\text { something special }\end{array}$ & 0.74 & 18.47 \\
\hline \multirow{2}{*}{$\begin{array}{l}\text { Obsessive-compulsive } \\
\text { buying }\end{array}$} & $0.884(\mathrm{a}=0.740)$ & Others might consider me as a shopaholic & 0.88 & 71.77 \\
\hline & & $\begin{array}{l}\text { Much of my time centers around buying } \\
\text { things }\end{array}$ & 0.89 & 86.23 \\
\hline \multirow[t]{2}{*}{ Idea shopping } & $0.909(\mathrm{a}=0.806)$ & I go shopping to keep up with the trends & 0.88 & 42.13 \\
\hline & & $\begin{array}{l}\text { I go shopping to keep up with the new } \\
\text { fashions }\end{array}$ & 0.94 & 107.74 \\
\hline \multirow[t]{3}{*}{ Role shopping } & $0.891(\mathrm{a}=0.847)$ & I enjoy shopping for my friends and family & 0.86 & 20.30 \\
\hline & & $\begin{array}{l}\text { I feel good when I buy things for the special } \\
\text { people in my life }\end{array}$ & 0.95 & 47.71 \\
\hline & & $\begin{array}{l}\text { I enjoy shopping around to find the perfect } \\
\text { gift for someone }\end{array}$ & 0.73 & 9.45 \\
\hline \multirow[t]{3}{*}{ Social shopping } & $0.891(0.819)$ & $\begin{array}{l}\text { I go shopping with my friends or family to } \\
\text { socialize }\end{array}$ & 0.88 & 19.61 \\
\hline & & $\begin{array}{l}\text { Shopping with others is a bonding } \\
\text { experience }\end{array}$ & 0.85 & 14.10 \\
\hline & & $\begin{array}{l}\text { To me, shopping with friends or family is a } \\
\text { social occasion }\end{array}$ & 0.82 & 12.03 \\
\hline \multirow[t]{3}{*}{ Value shopping } & $0.914(0.859)$ & $\begin{array}{l}\text { For the most part, I go shopping when there } \\
\text { are sales }\end{array}$ & 0.86 & 36.40 \\
\hline & & I enjoy looking for discounts when I shop & 0.88 & 49.86 \\
\hline & & I go shopping to take advantage of sales & 0.89 & 56.98 \\
\hline
\end{tabular}

Table 7. Hypotheses Assessment

\begin{tabular}{lccccc}
\hline & Hypothesized path & b-value & t-value & p-value & decision \\
\hline H1 & adventure $>$ ocb & 0.365 & 7.440 & 0.000 & Supported \\
H2 & gratification -> ocb & 0.112 & 2.435 & 0.014 & Supported \\
H3 & idea -> ocb & 0.292 & 7.955 & 0.000 & Supported \\
H4 & role -> ocb & -0.256 & 6.005 & 0.000 & Rejected \\
H5 & social -> ocb & -0.085 & 1.616 & 0.106 & Rejected \\
H6 & value -> ocb & -0.248 & 6.140 & 0.000 & Rejected \\
\hline
\end{tabular}

$\mathrm{ocb}=$ obsessive-compulsive buying 